\title{
LA SANGRE DEL NÚMERO
}

Mauricio López Noriega*

\section{Apenas se adivina Orión, hace horas} que se ocultaron las Pléyades. Soy un enamorado del saber y, como tal, encuentro en los avatares cotidianos signos de lo que será; como amante de los números y miembro de la Hermandad, estuve presente en la hecatombe para agradecer al Dios: la irrefutabilidad de la prueba que el Maestro reveló es símbolo de lo divino, cuyo atributo evidente es la eternidad; sin importar, pues, esa medida en la que no confío y que llaman tiempo, cualquier cuerpo en el cosmos cuyos tres ángulos, en total, alcancen media circunferencia, está contenido en aquella demostración.

Declina la noche y espero con ansiedad, aunque conozco al Maestro y puedo aguardar confiado su llegada. El descubrimiento al que me he acercado, con humildad aunque por una ocasión sin necesidad de su mano, lo dejó desde ayer sumido en un pozo de pensamientos. Tardé en comprender que el simposio no es el lugar idóneo para transmitir secretos; en ello cifro la reprimenda que sus ojos veladamente me hicieron, al tiempo que con firmeza, no exenta de ternura, me instó a no beber como los escitas. Sin embargo, añadió que vendría antes de que apareciera la aurora de rosados dedos. No ocultaré que le quiero y admiro: Él me enseñó, desde mi llegada de Metaponto que, para quienes los saben fatigar, los números revelan el Universo todo, pues son el mayor espejo para quien interroga con ojos adiestrados y afilada razón.

* Departamento Académico de Estudios Generales, ITAM. 
Con paciencia me hizo conocer las ternas, bellas combinaciones de números enteros: $\gamma$ ' dos veces por sí, y añadido a $\delta$ ' sujeto a la misma operación, obtiene como producto $\varepsilon$ ' dos veces por sí, lo cual suele aplicarse hermosamente a una cantidad suficiente de números, por decir $\imath \beta^{\prime}, \varepsilon^{\prime}, \imath \gamma^{\prime}$, si siguen la misma disposición. Asimismo, me ha mostrado la correspondencia numérica de los fenómenos naturales, pues si los números son enteros o pueden incluso fraccionarse sin perder su proporción, entonces son perfectos como perfecto es el Cosmos insondable. En ello descansaba mi paz, nuestra paz. Imposible olvidar cuando el sabio de Samos nos demostró con la tetracorde lira la serena armonía que emana de la fracción del entero: una octava arriba y el sonido es magnífico; tercios, cuartos, quintos, fracciones simples y se mantenía el equilibrio. Confieso que más tarde probé tanto con el bárbiton como con el báromos, e incluso con el mágadis de veinte cuerdas, y todo resultó abrumadoramente verdadero. Me maravillaba la claridad casi olímpica de su mente: es cierto que los poetas conocían el secreto de la armonía, pero ninguno procuró otorgarle la gracia de la demostración racional y, jamás, su sagrado significado.

Decidí seguir al Grande hasta la muerte; conozco el alcance de tal compromiso hasta el fin del aliento; por ello, he memorizado los versos del dulce Anacreonte, quien un tiempo compartiera con mi Maestro el rigor, y el lujo, del cetro de Polícrates, tirano en Samos:

pues el Hades es terrible abismo,

$y$ el descenso hasta él, funesto;

pues cierto, para quien desciende,

el no regresar.

Los días transcurrían, y los trabajos, en la serenidad de la investigación. Cierta tarde, inopinadamente, perfilada apenas, la sombra de una inquietud, de una duda oscureció mi mente: si la perfección del Universo es entera y divisible en fracciones proporcionales, ¿no será acercarse a los dioses demostrar que lo sublime es la perfección que contiene la imperfección en su origen? Indagué en torno a esta polícroma corazonada hasta adelgazar mi cuerpo, obtuve la certeza. ¿Me llamará, 
quizá, mi Maestro, señor de señores en el pensamiento y me invitará a discutir la demostración mientras miramos el ponto rico en peces?

Me cuesta trabajo no pensar en la gloria que junto con él he de compartir; él, ya famoso, crecerá en nombradía y estima por toda la negra tierra, desde Tracia hasta Tartesos, desde Teos hasta el lugar donde moran los pueblos que se alimentan de moluscos y sangre humana. A mí, me basta con acrecentar sus laureles. ¿Permanecerán nuestros nombres unidos como los de Aquiles y Patroclo?

¿De cuál ejemplo he de servirme? La sencillez en la prueba debe reflejar elegancia de espíritu. Óptimo será presentar el Número nuevo de la forma menos compleja y más diáfana: aún lo inconmensurable, no reductible por la razón, debe ser bello y bueno, ya que es verdadero. Solamente en la mano esta tablilla, y en ella el Número que es la evidencia de la más excelsa areté: $\sqrt{ } \beta$,

De mi propia mano, la emoción escribe que $\sqrt{ } \beta$ ' dos veces por sí mismo nos otorga lo imposible. Este resultado, maravilla tornasolada, ¿entusiasmará al Maestro del mismo modo que a mí?

Febo lanzó sus corceles y el cielo se tiñó de suave púrpura. Los pasos que se acercaban dejaron de escucharse. Se abrieron las dobles puertas y la voz de Pitágoras resonó en el espacio.

-El Universo es Uno, perfecto, armónico, y sólo lo que podemos captar con la razón subsiste.

Sus ojos se agrandaron y la voz retumbó, fragua dentro de su pecho.

-Fuiste el mejor de los alumnos, y no he de ocultar que tal vez te amé. Pero es imposible permitir la existencia de este Número infame. ¿Qué sería del Universo? ¿En dónde habría de buscarse la inteligente Proporción que es Orden y Belleza? Mas, si callas para siempre, nadie conocerá este ignominioso secreto. La Hermandad, a salvo, y con ella los pueblos de la Tierra prolífica, olvidarán tu nombre.

Y completó con rudeza:

-Te permito partir. 
La confusión cegó por un instante la mente del discípulo. Como si las Furias, persiguiéndole, se apiñaran a su alrededor, torpemente se adelantó a tumbos. No escuchó, ya, la orden que el Maestro impartió a los sicarios, quienes, resguardados por los jirones de la noche, hicieron centellear con habilidad las hojas de sus dagas; penosamente, arrojaron su cadáver al mar. La Hermandad siempre sostuvo que Hippasio nunca alcanzó destreza alguna en las artes del reino de Poseidón. 